\title{
Historical Abuse - A Contemporary Issue: Compiling Inquiries into Abuse and Neglect of Children in Out-of-Home Care Worldwide
}

Johanna Sköld

\section{Linköping University Post Print}

\section{Tweet}

N.B.: When citing this work, cite the original article.

This is an electronic version of an article published in:

Johanna Sköld, Historical Abuse-A Contemporary Issue: Compiling Inquiries into Abuse and Neglect of Children in Out-of-Home Care Worldwide, 2013, Journal of Scandinavian Studies in Criminology and Crime Prevention.

Journal of Scandinavian Studies in Criminology and Crime Prevention is available online at informaworldTM: http://dx.doi.org/10.1080/14043858.2013.771907

Copyright: Taylor \& Francis (Routledge): SSH Titles http://www.routledge.com/

Postprint available at: Linköping University Electronic Press http://urn.kb.se/resolve?urn=urn:nbn:se:liu:diva-90938 
Historical abuse - a contemporary issue: compiling inquiries into abuse and neglect of children in out-of-home care worldwide 
Corresponding author:

Johanna Sköld

$\mathrm{PhD}$, lecturer

Child Studies, Department of Thematic Studies

Linköping University

58183 Linköping

SWEDEN

E-mail: Johanna.Skold@liu.se 


\section{Abstract}

Since the 1990s, abuse and neglect in institutions and in foster homes for children in out-of-home care have been reviewed by inquiries and truth commissions in several countries. State and federal or regional commissions have interviewed, set up hearings with or collected written submissions from people who claim to have been subjected to abuse and neglect whilst in care. In many respects, truth commissions and inquiries into past abuse and neglect share features characteristic of transitional justice processes. However, said inquiries and truth commissions have only occasionally attracted attention in the broad scholarly field of transitional justice. The aim of the article is to compile inquiries into abuse and neglect in out-of-home care that have been conducted worldwide in order to frame the historical context in which these inquiries and truth commissions were set up. Furthermore, this article argues that a comparative perspective can highlight important epistemological issues, such as what knowledge is produced in the inquiry reports and how a historical understanding of past abuse and neglect of children in out-of-home care is framed. The article points out some possible areas for future research that may constitute a new interdisciplinary field within the field of transitional justice.

Keywords: abuse, neglect, child, foster home, out-of-home care, inquiry, truth commission, transitional justice, care leaver 


\section{Ireland}

'Br...X... caught me and he brought me up to the dormitory, he let down my trousers and he lashed me. He always wore a leather, around 18 inches ... (long)... and it was all stitched with wax, his leather was very thin. It was about an inch and a half, others had leathers about 2 inches. He lashed me, he flogged me.' (CICA 2009: vol 3, 7.28)

\section{Sweden}

'Virpi describes her foster mother as a lunatic: "She kept a book where she wrote down every single thing I did." Virpi's foster mother beat her with a wet birch switch, a leather strap, a carpet beater, canes, and clenched fists. In most cases Virpi was hit on her back and legs, but occasionally even on the head. She also had her legs stuck with pins that her foster mother always had in reach, since they were attached to the hem of her skirt. This happened several times a week.' (Female born in the 1930s, SOU 2009:99: 188)

\section{Denmark}

'Q1962 describes how all boys were lined up and how each boy had to hit or kick the "guilty boy". The boys were forced to get back into the line and punch him once more. The "guilty boy" could receive 50 punches in the face.' (Male born in the 1960s, Rytter 2011:78.)

\section{Australia}

'The foster family would punish me severely for the slightest thing they regarded as unacceptable or unchristian behaviour, even if I didn't eat my dinner or tea. Sometimes I would be locked in my room for hours. Countless times the foster father would rain blows 
upon me with his favourite leather strap. He would continue until I wept uncontrollably, pleading him to stop.' (Male born in the 1960s, HREOC 1997:60-61)

These quotes are all painful testimonies of child abuse. These are abusive situations that took place in the past when the individuals behind these quotes - men and women who have testified before commissions that have been established to inquire into abuse and neglect in out-of-home care - were children. The testimonies are collected in an adjacent present; however, this is a time when abuses in the past have become a contemporary political issue in several countries.

Since the 1990s, abuse and neglect in institutions and in foster homes for children in out-of-home care have been reviewed by inquiries and truth commissions in at least nine countries: Australia, Canada, Ireland, Norway, Iceland, Britain, Sweden, Denmark, and Germany. State and federal or regional commissions have interviewed, set up hearings with or collected written submissions from people who claim to have been subjected to abuse and neglect whilst in care. Similar inquiries have also been conducted by the Catholic Church, after accusations of abuse in several countries (Gosh, Israely and Moore 2010; John Jay College of Criminal Justice 2004; Michelson 2010).

The aim of this article is to compile inquiries into abuse and neglect in out-of-home care that have been conducted worldwide in order to frame the historical context in which these inquiries and truth commissions were set up. Furthermore, this article argues that a comparative perspective can highlight important epistemological issues, such as what knowledge is produced in the inquiry reports and how a historical understanding of past abuse and neglect of 
children in out-of-home care is framed. A warning is in order, however: this article reveals more questions than answers. It points out some possible areas for future research rather than giving a complete overview of the field of inquiries into the abuse and neglect of children in care.

\section{Similar stories from different national contexts}

The quotes above are all collected from state and regional commission reports. They have not been selected to create offence or revulsion in the reader, although such reactions are of course possible and perhaps even reasonable. The quotes illustrate that the content of such investigations is based on compilations of traumatic memories and that the informants' descriptions of abuse in different countries have a great deal in common.

These particular quotes describe events of physical abuse. Two give accounts of physical abuse in institutions, while the other two illustrate foster parents punishing their foster children. The quotes speak of physical abuse with fists and belts as well as other types of weapons. These examples of abuse could easily have been taken from any of the published reports, because the descriptions of physical abuse found in the reports are quite similar regardless of the geographical origins of the interviewees and the commissions.

Irrespective of country of origin, the informants have told partially similar stories about an existence marked and sometimes defined by physical violence, emotional violation, sexual abuse, exploitation, and neglect, all of which occurred for the better part of the twentieth century (Penglase 2007:40). The similarity amongst the testimonies is especially interesting since the countries that 
have conducted inquiries or truth commissions represent different contexts of welfare policies and have organized the care of orphaned, neglected, and abused children in different ways. The background and premises of the inquiries have varied as well. This, in turn, has influenced how maltreatment has been explained in the inquiry reports. Even though the inquiries and truth commissions differ from one another in many respects, it is important to note that they have also been inspired by each other. This means that inquiries investigating different contexts may have departed from similar starting points and applied similar methods (see for example Brennan 2007:260).

It has been known for some time, even before the establishment of the inquiry commissions, that some children in care have been exposed to abuse and neglect (Coldrey 2001; Garrett 2010; Sen, Kendrick, Milligan \& Hawthorn 2008). What is new about the inquiries from the 1990s onward is that the victims themselves have been given the opportunity to tell their stories; that the stories have gained the attention of the media; and that there have been expectations that these testimonies should influence the national historical narrative and national identity and that this, in continuation, would lead to a process of reconciliation and redress as well as actions to prevent future abuse.

A compilation of inquiries worldwide, which in no way claims to be complete, shows that such inquiries have collected oral and written testimonies of abuse and neglect from more than 5,000 people (see appendix). If we include autobiographical stories from those who have applied for economic compensation in countries that have established redress schemes, the testimonies come from tens 
of thousands of people. Only in Ireland, the state has paid compensation to more than 13,000 individuals. In Norway at the end of 2009, 2,600 individuals had been awarded compensation (Pettersen 2010:46, Residential Institutions Redress Board 2010:24).

With this article I want to highlight the fact that historical inquiries and redress and reconciliation processes for abused and neglected children in out-ofhome care are underway in several parts of the world, and that studies of these processes may constitute a new interdisciplinary field. The fact that the redress boards and inquiry commissions have, without any intentional purpose, collected enormous amounts of source material from care leavers could be relevant to scholars from different disciplines such as childhood history, criminology, social work etc. However, several issues are at stake here: is it ethically and practically possible to partake of the documented and recorded interviews, hearings and written submissions from informants? And subsequently, what knowledge can be gained from inquiry reports and informants' stories? (Ericsson 2011). It is also important to consider, as Nell Musgrove suggests, how we as professional historians and scholars can engage in these questions in an empathetic and professional way without positioning ourselves as experts with the interpretative prerogative (Musgrove 2011).

The testimonies from care leavers who have survived harsh abuse and neglect or forced removals from their parents and kin challenge the prevailing notions of the child welfare system as well as notions of countries' national selfidentity as modern, democratic and tolerant welfare states. These are naturally 
insights that could be difficult to come to terms with on a national level. In effect, the validity of oral and written testimonies collected by inquiries and redress boards has become politicized in several countries, which, in turn, has paved the way for discussions about the concept of truth and how the inquiry commissions have construed the stories told (Sköld, Foberg \& Hedström 2012; Attwood 2005; James 2012). Kjersti Ericsson has stressed that the inquiry reports have their blind spots and biases (Ericsson 2011). A way to illuminate these shortcomings and common assumptions is to submit the inquiry reports to comparative analysis. How abuse and neglect are defined within a historical perspective, which stories of abuse are highlighted and which remain in silence, which forms of out-of-home care are in focus, how the stories told are interpreted, and how one can explain cruelty to children are all questions that can be problematized if they are considered from a comparative perspective. ${ }^{1}$ Another question deals with what the establishment of inquiries tell us about the current times we live in and why the inquiries are being conducted just now.

\section{The genealogy of inquiries and reconciliation processes}

The upsurge of inquiry reports on abuse of children in care first occurred in Australia and Canada during the 1990s, when the notion of the separation of Aboriginal children from their families and kin was exposed in the media. In these cases, the separation was characterized by colonial racist assimilation policies.

\footnotetext{
${ }^{1}$ This is the theme of my current research project, 'Inquiries into child abuse and neglect in institutions and out-of-home-care: a comparative perspective and a contribution to the international history of children in public care', financed by the Swedish Council for Working Life and Social Research.
} 
Eventually, at least in Australia, inquiries have also examined the experiences of socalled child migrants, who were sent overseas from the UK and Malta to Australia, New Zeeland, Canada and Zimbabwe (formerly Rhodesia). This overseas migration was motivated with various reasons, but an overshadowing context was the British colonization of the world from the seventeenth century until the 1960s. In the case of child migration to Australia after World War II, one objective was to ensure a white British population in the sparsely populated Australia by migrating war orphans from the UK. During the late 1990s, calls from groups and individuals for an independent inquiry into the child migration increased. Such an inquiry was launched in 2000 and published its report in 2001 (Australian Senate Community Affairs References Committee 2001:13-25). In parallel with this process, abuses of children in state care were investigated by inquiry commissions in several federal Australian states and a national report was published in 2004 (Australian Senate Community Affairs References Committee 2004).

In Canada, several regional redress programmes relating to child abuse in institutional settings were established in the 1990s (Llewellyn 2002: 258-261, Shea 1999). Alongside these redress programmes, the Royal Commission on Aboriginal Peoples recognized that the conditions in residential schools, where as many as 150,000 Aboriginal children had been placed, needed closer examination as many former inmates told of severe abuse and neglect. The Indian Residential Schools Truth and Reconciliation Commission was set up in 2008 on a mandate to operate for five years, and was to report its work by March 2013; however, the report is likely to be delayed (James 2012:184-185, 189). 
From the mid-1990s onward, British inquiries which are regional in scope have investigated institutional abuse and neglect. However, the social welfare services for children have included not only institutions but other forms of out-of-home care as well. In Scotland many children have been boarded out to foster homes, whilst institutional care has been more common in England and Wales (Abrams 2001: 198). Still, the inquiries in the UK mainly concern institutions, not foster homes (Corby, Doig and Roberts 2001). In 2012, two new regional inquiries with a focus on abuse in institutional settings have been launched: the Northern Ireland Inquiry into clerical child abuse in religious-run institutions in the province and the Scottish National Confidential Forum - A consultation on the creation of a Forum for Adult Survivors of Childhood Abuse in Residential Care (McDonald 2012; The Scottish Government 2012).

The Catholic Church has run many of the industrial schools and children's homes in Ireland, Canada and Australia. The abuse and neglect disclosed by the so-called Ryan Commission in Ireland, which operated from 1999 to 2009, came to be associated with the Catholic Church (Garrett 2010: 303).

Inquiries in the Nordic countries were launched in the 2000s. For most of the twentieth century, the Nordic countries have organized their social welfare services for children within the scope of a social democratic welfare regime. The responsibility for placed children has rested upon the state and local municipalities rather than church or voluntary organizations - this is true, at least, for the period after the 1950s. However, there are some similarities between the maltreatment reported in the Nordic countries and that in the British, Irish, Canadian and 
Australian inquiries. To some extent, this may be because Norway and Iceland have focused mainly on abuse and neglect in institutions despite the fact that boarding children in foster homes has been common in these countries (Andresen, Garðarsdóttir, Janfelt, Lindgren, Markkola \& Söderlind 2011:166).

The Swedish commission differs from several other Nordic inquiries as it placed just as much emphasis on abuse and neglect in foster homes as in institutions. The Swedish inquiry, moreover, was conducted on a national level and includes stories from institutions and foster homes from the entire country (Sköld, Foberg and Hedström 2012:16), whilst inquiries in Norway, Denmark and Iceland have investigated regional or municipal care. ${ }^{2}$

Like Australia and Canada, some of the redress and reconciliation processes in Norway concern children of national minority groups. The treatment of German soldiers' children born in Norway during the German occupation in World War II, as well as assimilation politics involving Travellers and the Sami and Kvaeni peoples, have been the source of a great deal of debate (Pettersen and Simonsen 2011, Olsen 2005; Ericsson 2009: 33-38). In Sweden and Denmark, redress to minorities who have experienced harsh treatment and assimilation politics is still a peripheral theme in comparison to Norway. However, in recent years assimilation politics have gained some attention in the political sphere as well as in the media in Sweden and Denmark. In early 2011, the Swedish minister of integration charged the Ministry of Labour with establishing a white paper, which

\footnotetext{
2 Norway has conducted a national investigation on historical aspects of care in children's homes. However, this investigation has not interviewed care leavers but is rather based on a number of regional studies and research reviews. See NOU 2004:23. Barnhjem og specialskoler under lupen. Nasjonal kartleggning av omsorgsvikt og overgrepp i barnevernsinstitutusjoner 1945-1980, Oslo.
} 
is a kind of truth commission, aiming to address the suffering and history of the

Romani people in Sweden (Press release from the Ministry of Labour, Sweden,

January 31 2011). In Denmark, a movie - Ekseperimentet - depicting 20

Greenlandic children who were forced to move to Denmark in 1952 attracted some

attention to the Danish assimilation policy regarding Greenland when the movie

premiered in 2010. In effect, the Danish Save the Children Fund, one of the parties

involved, apologized and launched an investigation of their own (Danish Save the

Children Fund 2010).

\section{Transitional justice and the politics of apology}

In many respects, truth commissions and inquiries into past abuse and neglect

share features characteristic of transitional justice processes, that is, a willingness to come to terms with history and 'making whole what has been smashed' - an

expression borrowed from the sociologist John Torpey (Torpey 2006). ${ }^{3}$ The redress

and reconciliation of historical wrongs has almost become an international trend.

As the historian Elzar Barkan stated in 2000, after studying several cases in which

states subsequently assumed the guilt and responsibility for atrocities in the past,

this says something significant about our time (Barkan 2000:317-322). Even if the

\footnotetext{
${ }^{3}$ Alongside transitional justice, a concept like restorative justice has been discussed by criminologists during the past decade. As K Clamp and J Doak stress, while the concept of restorative justice lacks a precise definition, an important feature is the underlying assumption that a dialogue between victims, perpetrators and broader society can bring about healing aspects for victims and a better understanding of the causes that resulted in an offending act (Clamp and Doak 2012:342). Restorative justice can refer to the juridical practice of mediating between victim and offender that has frequently been used in countries such as Finland and Norway since the 1980s and 1990s, respectively (Albrecht 2010). It can also be applied to the establishment of truth commissions and symbolic reparations of past violations of human rights. In effect, there exists a paradigmatic overlap between the discourses of restorative justice and transitional justice (Clamp and Doak 2012: 340-341). In relation to the topic at stake here - historical inquiries into past abuse and the neglect of children in out-of-home-care - it is important to distinguish between restorative justice for quite contemporary crimes and restorative/transitional processes of bringing to justice past abuses and atrocities that would not necessarily have been regarded as crimes at the time of the events.
} 
international political arena has changed since Barkan wrote his book, this trend seems to be here to stay. Today, not only states but also multinational enterprises and religious communities have apologized for atrocities of which they have been a part (Marrus 2008; Ibhawoh 2008). A so-called 'politics of regret' characterizes our time, according to the historical sociologist Jeffrey K. Olick. He argues that regret is a modern expression of political responsibility (Olick 2007:130-132).

The concept of transitional justice was established in the mid-1990s (Bell 2009:7). However, the phenomenon itself has its roots in the post-war era, when the need for settlement with the crimes against humanity during World War II was pressing. Initially, transitional justice focused primarily on accountability and on bringing perpetrators to trial. Later, as human rights advocacy developed, transitional justice came to include other solutions for achieving reconciliation and restitution (Bell 2009:13; Torpey 2006:159). Immediately after the war the Nuremberg Trials, aiming to bring to justice the perpetrators responsible for the Nazi crimes, were initiated. In the decades since, this first step towards transitional justice has been followed by not only extensive accordments and processes of restitution and redress associated with the Holocaust, but also processes investigating war crimes committed by non-Germans, for example the Japanese (Torpey 2001:335; Hein 2003).

A new era of transitional justice began in the 1970s, when truth commissions became a necessary ingredient in the transition to democratic governance in some countries in Central and South America. Eventually, similar truth commissions were initiated in Eastern Europe as well as Africa, where the 
South African Truth Commission, which operated from 1995 to 2002, reached extraordinary fame. These truth commissions have investigated the wrongs and terror that dictatorial or authoritarian regimes committed against their people, and have comprised an effort to justify new democratic regimes and unite nations shattered by ethnic conflict (Hayner 2011; Torpey 2001:336; Bell 2009:7).

During the 1990s, discussions on transitional justice came to be directed at colonial practices that have enslaved or deprived indigenous peoples and ethnic minorities of their lands, lives, and cultures (Torpey 2001:335).

The literature on transitional justice is broad and interdisciplinary in nature. Since 2007, the field has its own journal - the International Journal of Transitional Justice -which has very quickly gone from establishment to critique (Bell 2009:13), with historians asserting an essential part of the critical perspectives. Among other things, they have been dedicated to historicizing truth commissions and memory politics. Jeffrey K. Olick, Jay Winter, Bain Attwood, et al. have argued that, in our time, memories of traumatic experiences are viewed as carriers of truth about the past (Olick 2007; Attwood 2005:50-51: Winter 2001). Or, as Winter has expressed it: 'The person who suffered knows about mystery - the mystery of evil and the miracle of survival - and we who listen thereby enter the mystery and share the miracle' (Winter 2001:56).

The fact that the political gaze today turns towards the past instead of the future, John Torpey explains, is mainly an effect of the collapse of the major social theories, which has led many contemporary progressive thinkers to see 'the past rather than the future as the realm that could be fixed' (Torpey 2006:159-160). 
Jay Winter sees the memory boom partly as a result of the economic and educational prosperity of the late twentieth century in the West. This prosperity led to a demand for cultural goods, which in turn laid the foundations for the commodification of memories (Winter 2001:58-59). Olick refers to the decline and erosion of the idea of a nation-state and the rise of other memory-bearing units (Olick 2007:137).

Many scholars see this phenomenon in the light of an emergence of identity politics in which groups challenge the national narrative and the official history on what is considered historically interesting and important (Olick 2007:189-192; Winter 2001:55; Torpey 2006:161; Attwood 2005:55). These arguments can be seen as a counterpart to Nancy Fraser's description of the post-socialist era dilemma: political activism today strives for the recognition and rights of certain groups rather than aiming for the redistribution of resources in society (Fraser 1995).

It is tempting to view the inquiries into abuse and neglect as part of the contemporary memorial discourse, and as an expression of the political trend of transitional justice in which regret, apologies, and redress play a major role. However, inquiries into the abuse and neglect of children in out-of-home care have only occasionally attracted attention in the broad scholarly field of transitional justice. ${ }^{4}$ In fact, such inquiries and redress processes seem to be relatively neglected in the international scholarly literature on transitional justice, with the exception of reports and apologies concerning the care and treatment of ethnic minority children

\footnotetext{
${ }^{4}$ A search in the International Journal of Transitional Justice using the words 'child', 'abuse', and 'inquiry' resulted in 39 hits, but only one item explicitly considered inquiries into the abuse and neglect of children in outof-home care.
} 
(see, for example, James 2012). One reason for this is that to date there has been no concerted effort to compile all the inquiries into abuse and neglect throughout the world. Another reason is that inquiries into abuse and neglect in out-of-home care for children differ from traditional truth commissions in several respects, which I shall return to.

\section{Differences between the mainstream truth commissions and inquiries into the} abuse and neglect of children in out-of-home care

How truth commissions and inquiries into abuse and neglect should be incorporated into the historiography of transitional justice is a question for future research. However, some issues call for consideration intermediately. All truth commissions or redress projects in history are not equivalent and do not encounter the same problems (Siriam 2005:512; Bell 2009:14-15; Barkan 2000:319). Some scholars, like Olick, criticize studies of transitional justice on the grounds that literature in this field can hardly explain the origin of the politics of regret because transitologists compile cases from scattered times and places into one single model of transitional justice (Olick 2007:129).

A difference between mainstream truth commissions and inquiries into abuse and neglect is that the inquiries of past child abuse usually do not indicate a dissociation from or settlement with a former regime.

Another difference is that they are built upon adults' memories of their childhoods, not on memories of historically specific events or memories of a certain era. Consequently, one could assume that the past in the inquiry reports relates more to autobiographical memories than to collective ones. However, this 
conclusion is by no means obvious. The very process surrounding inquiries into these matters can shape collective memories and 'truths' about how municipal or state child welfare has operated and failed. Furthermore, it is important to note that individual and autobiographical memories are not created in a historical vacuum they are influenced by the contemporary context in which they are recalled and how they have been retold over the years (Abrams 2010).

The dispute over whether the testimonies in the inquiry reports are based on individual or collective memories is associated with another question: do the abused and neglected adults who have now come forward to tell their stories constitute a particular group with shared interests, or are they a loose assembly of individuals who happen to share similar experiences and can only be perceived as a collective after the inquiry commissions have described them as such in their reports? Or, to put it another way, are the inquiries a result of a collective identity and recognition-driven struggle amongst abused and neglected care leavers, or do they constitute groups and collectives that were non-existent before the inquiry commissions were launched?

As Joanna Penglase states, people who have been in out-of-home care as children, whether or not they were abused, have been invisible to the public, both as children and later as adult care leavers (Penglase 2007:59). Adequate statistics on how many children have been subjected to care, as well as satisfactory documentation on individuals' time in care, are surprisingly often lacking. Additionally, knowledge of how life turned out for adult care leavers was sparse before the inquiry commissions started asking these questions of the care leavers 
themselves (Penglase 2007: 311-312, 352-355). However, care leavers have not only been undetectable on a societal level; individuals have also sought to hide and forget the fact that they were placed in institutions or foster homes during childhood, since this part of their history is associated with shame, guilt and feelings of worthlessness (Penglase 2007:314-315). It is therefore important to note that the processes of an inquiry commission's work can create collectives that did not exist before the issues of abuse and neglect became politically relevant, and that some inquiries have been brought about by pressure from human rights organizations or groups of care leavers who amassed around a group's interests to have their suffering acknowledged and compensated for.

In this respect there are some contrasts between inquiries from different countries as well as between inquiries within a nation. In Canada, former inmates of two residential schools founded associations that have successfully negotiated with the state to obtain redress and economic compensation without any independent inquiry having first been conducted. ${ }^{5}$ In other cases, politicians and church organizations set up inquiry commissions after it became acknowledged through the media or police reports that abuse and neglect had occurred in certain named institutions (Shea 1999).

In Australia, clients' organizations and care leavers' associations have played a significant and successful role in bringing about inquiries concerning

\footnotetext{
${ }^{5}$ One such organization is the Grandview Survivors' Support Group (GSSG), which during the early 1990s gathered women who had been in care at the Grandview Training School for Girls in Ontario. The GSSG negotiated a compensation agreement with the government. Another similar organization is Helpline, which began as a support group for men who had been inmates at St. Joseph's Training School or St. John's Training School, and during their time in care had suffered abuse and neglect from the Christian Brothers who ran these institutions. Helpline managed to negotiate compensation with the responsible institutions. See Shea 1999:28-29, 35 .
} 
indigenous child removal, child migrants and, eventually, abused and neglected children in state care. Several organizations have their roots in the 1980s and have thus been around a long time. ${ }^{6}$ Moreover, television documentaries about child migrants (Lost Children of the Empire, 1989) or the forced removal of Aboriginal children (Lousy Little Sixpence, 1983) have also contributed to public attention to and political awareness of these issues (Attwood 2005:84; Swain 2011). In Norway, organizations have insisted on bringing about independent inquiries, recognition and financial compensation (Pettersen and Simonsen 2011). ${ }^{7}$

By contrast, in Ireland, Sweden and Denmark, issues of the abuse and neglect of children in out-of-home care have reached the political agenda only after shocking revelations of abuse have been disclosed in television documentaries and in other media. Individuals and organizations have also tried to get the attention of the legal system and politicians, but these efforts do not have as long a history as those in Australia. Rather than paving the way for inquiries for decades, organizations have been formed around the times when inquiry commissions have been launched. In Denmark, a television documentary broadcast in 2005 about the evils of the boys' home Godhavn resulted in the establishment of a care leaver association, which, in turn, has struggled for an impartial inquiry to be pursued efforts that paid off in 2010 (Rytter 2010:27-28).

\footnotetext{
${ }^{6}$ Link-Up, an organization dedicated to reuniting Aboriginal families separated by the child transfers (child removal) was founded in the early 1980s (Attwood 2005:82). The Child Migrants Trust is a lobbying organization formed in 1987 by the British social worker Margaret Humphreys. The organization has worked to call attention to the British children's migrations to Australia, and to reunite child migrants with their families (Child Migrants Trust home page: http://www.childmigrantstrust.com/our-work).

7 A leading organization in Norway has been Rettferd taperne (Justice for losers), formed in 1993 (converted to a foundation in June 1999). The first inquiry in Norway was conducted in the Bergen area in 2003.
} 
The extent to which these groups, organizations and associations have influenced the work of inquiry commissions and redress processes in different countries is something for future research to tell. However, a comparative perspective highlights the client organizations' varying success in initiating inquiries and redress processes. The media seem to have played a prominent role in most countries that have carried out inquiries into abuse and neglect. We can assume that both collective and individual memories have shaped the metanarrative of abuse which appears in the media, inquiry reports, and apology politics. However, it is not evident that all abused care leavers identify with the history told or that they constitute a homogeneous group. Pettersen and Simonsen (2011) therefore stress that it is relevant to ask '... how those applicants relate to the standardized meta-narratives circulated in public about marginal/disadvantaged groups. Are there hierarchies of different "loser identities"?'

The fact that inquiries into the abuse and neglect of children in out-ofhome care do not reflect any specific historical events has frequently contributed to wider time frames than other truth commissions, which characteristically cover one or two decades. ${ }^{8}$ The shortest time frame for any inquiry commission in my compilation covers 25 years; this is the Report from the inquiry commission in Kristiansand, Norway, which encompasses 1954-1979. However, it is much more common that the inquiries span most of the twentieth century. The most widespread single inquiry, the Irish Ryan Commission, encompasses stories of abuse from 1914 to 2000 . Time frames often stretch beyond these borders and into

\footnotetext{
825 of the 40 truth commissions that Priscilla B Hayner lists in her well-known survey cover 20 years or less
} (See Hayner 2011:256-284). 
the future, as many reports contain suggestions and recommendations for how the contemporary and future social welfare of children can be improved (SOU 2011:61: 298-308; Waterhouse 2000: chapter 56; Tasmanian Ombudsman 2004: chapter 7).

Ambitious time frames of course represent a methodological challenge for the inquiry commissions. Another challenge is to identify abuse and neglect in historical contexts. Since the inquiry commissions interview informants who tell of events in the past when the methods of discipline were different from today's standards, the definition of what should be regarded as abuse or neglect, and what should not, is an undertaking of complex dimensions. What has been perceived as abuse or neglect at one time may not necessarily be understood in the same way at another moment in history (Ferguson 2007). A wide time frame is likely to have further complicated this task. Comparative studies may help illuminate how different inquiry commissions have solved this dilemma.

Perceptions of the notion of the 'best interest of the child' have varied not only over time but also between different spatial and cultural contexts. For example, countries that have undertaken inquiries into the abuse and neglect of children in out-of-home care have different attitudes regarding the corporal punishment of children. Since 1979 all physical correction of children is prohibited in Sweden, while in Australia one is still allowed to physically punish children (Holzer and Lamont 2010:1). Other countries in this survey that have introduced a ban on corporal punishment are Norway (1987), Denmark (1997), Germany (2000), and Iceland (2003) (Rädda barnen 2012). These prohibitions apply to the right of parents to correct their children through physical punishment, yet there are 
prohibitions related to other child-rearing practices that have been in effect for a much longer time. For example, corporal punishment in comprehensive school was prohibited in 1936 in Norway and in 1958 in Sweden. At children's homes and residential schools, corporal punishment was prohibited in 1953 in Norway and in 1960 in Sweden, meaning that a certain amount of the abuse reported to the commissions was considered criminal at the time of the events (SOU 2009:99:100101; Fylkesmannen i Sør-Trøndelag 2007:21).

In Canada, Great Britain and Ireland, corporal punishment in the schools was banned in 2004, 1986/1998 and 1982, respectively, but parents still have the right to physically chastise their children in these countries (Axelrod 2010:262; Maguire and Cinnéide 2005:648). Contemporary perceptions of what is acceptable or unacceptable treatment of children are likely to have an impact on what kinds of mistreatment people tell about and how abuse and neglect are defined in different national contexts.

Transitional justice is a cloak 'that aims to rationalize a set of diverse bargains in relation to the past', rather than a coherent field, in the words of Christine Bell (2009:6). The examples above suggest that inquiries into abuse and neglect have their own special features, which in some respects makes them incompatible with other truth commissions and reconciliation processes. A branch of transitional justice that does, however, have clear links with inquiries on abuse and neglect is found in the apologies and restitution processes concerning unethical medical care and research. One such example is President Bill Clinton's apology in 1997 for a medical experiment conducted on black men in Alabama from 1932 until 
the 1970s (Hayner 2011:15). Sterilizations are another well-known theme. The practice and consequences of forced sterilization have been investigated in different countries and in some cases, such as that of Sweden, these have also led to processes of redress and apology (SOU 2000:20; Braun 2011).

\section{Why now?}

Care that has resulted in maltreatment, abuse and injury is a common theme in sterilizations, medical experiments and the neglect of children. The concept of care is associated with good intentions; however, care in practice is not always synonymous with the intentions. How is it possible that efforts undertaken with good intentions have caused so much pain and disaster? And why are these abuses and atrocities attracting attention right now?

In some countries, explanatory models pointing to the welfare state's dark side seem to be adequate (Arvidsson 2011: 26; Pettersen and Simonsen 2011) whereas in other countries the absence of a strong welfare state appears to be a part of the problem. In Ireland, where the Catholic Church has had a prominent role as the head of children's institutions and carried out a significant part of the day-today running of institutions, the state's faith in the Church has been viewed as the root of the problem (Garrett 2010:303; Smith 2001). Parallels can be drawn to Australia and Canada, where church organizations have also had significant influence on and responsibility for social welfare services directed towards children (Llewellyn 2002). A social climate or political discourse that allows challenges to certain hegemonic structures, whether hegemony is represented by the good, 
paternalistic state or the almighty Church, likely contributes to the soil that allows the growth of processes of recognition and reconciliation (Smith 2001).

A new field of study must be open to many different explanatory models and hypotheses. Whilst inquiries into abuse and neglect, as well as various processes of redress, take place in an 'age of apology', these cannot obscure the fact that the stories of abuse now being told also appear within a certain context in the history of children. Today there are linguistic prerequisites for talking about and describing abuse, and this is especially true for child sexual abuse. Until recently, child sexual abuse was taboo and could only be spoken of through paraphrase (Jackson 2000:55-56). Most likely, linguistic practice has influenced what was possible to see and pay attention to, and by consequence, to act upon. In particular, an awareness of boys also being potential victims of sexual abuse revolutionized the gaze and content of child sexual abuse.

Inquiries into the abuse and neglect of children in out-of-home care are being carried out in an age where children have been identified as a group with certain human rights in international documents such as the UN Children's Convention, adopted in 1989. What impact has this had on the appearance of inquiries and redress processes linked to childhood?

The abuse and neglect of children in out-of-home care are almost certainly not limited to those countries that have undertaken investigations of this kind. But how can we understand why these questions have been raised so far in 
the Nordic countries, Germany and several Anglo-Saxon countries? Where can we expect more inquiries in the future? ${ }^{9}$

\section{References}

Abrams L (2001). 'Blood is Thicker than Water': Family, Fantasy and Identity in the Lives of Scottish Foster Children. In Lawrence J, Starkey P (eds). Child Welfare and Social Action in the Nineteenth and Twentieth Centuries: 195-219. Liverpool: Liverpool University Press.

Abrams L (2010). Oral History Theory. New York: Routledge.

Albrecht B (2010). Multicultural Challenges for Restorative Justice: Mediators' Experiences from Norway and Finland. Journal of Scandinavian Studies in Criminology and Crime Prevention 11:3-24.

Andresen A, Garðarsdóttir Ó, Janfelt M, Lindgren C, Markkola P \& Söderlind I (2011).

Barnen och välfärdspolitiken: nordiska barndomar 1900-2000 [Children and welfare politics: Nordic childhood 1900-2000]. Stockholm: Dialogos förlag.

Arvidsson M (2011). Ett mörkt kapitel i vår historia [A dark chapter in our history]. Locus 2: 25-38.

Attwood B (2005). Telling the truth about Aboriginal history. Crows Nest, NSW: Allen \& Unwin.

Australian Senate Community Affairs References Committee (2001). Lost Innocents: Righting the Record Report on Child Migration. Canberra: Senate Printing Unit.

Australian Senate Community Affairs References Committee (2004). Forgotten Australians: A report on Australians who experienced institutional or out-of-home care as children. Canberra: Senate Printing Unit.

Axelrod P (2010). No Longer a 'Last Resort': The End of Corporal Punishment in the Schools of Toronto. The Canadian Historical Review 19(2):261-285.

Barkan E (2000). The guilt of nations. Restitution and negotiating historical injustices. New York: Norton.

\footnotetext{
${ }^{9}$ Some indications point to other nations considering conducting inquiries. According to a radio interview with Permanent Secretary Päivi Sillanaukee at the Ministry of Social Affairs and Health in Finland, there are plans to establish a group within the Ministry that would be charged with investigating whether an inquiry similar to the Swedish one should be established in Finland. However, no group within the Ministry for working with these issues had yet been assembled when the radio programme Radar was broadcast on $9^{\text {th }}$ March 2012. Listen to the programme at: http://arenan.yle.fi/radio/1593014/ (accessed 2012-10-31).
} 
Bell C (2009).Transitional Justice, Interdisciplinarity and the State of the 'Field' or 'NonField'. The International Journal of Transitional Justice 3:5-27.

Braun K (2011). Historic Justice and biopolitical rationality: Coming to terms with historic sterilization policies. Paper presented at the conference 'The Study of Eugenics', Uppsala, November 10-11 2011.

Brennan C (2007). Facing What Cannot be Changed: The Irish Experience of Confronting Institutional Child Abuse. Journal of Social Welfare \& Family Law 29: 245-263.

Child Migrants Trust. Home page: http://www.childmigrantstrust.com/our-work (accessed 2012-10-25).

CICA The Commission to Inquire into Child Abuse (2009). Report of the Commission to Inquire Into Child Abuse. Dublin.

Clamp K \& Doak J (2012). More than Words: Restorative Justice Concepts in Transitional Justice Settings. International Criminal Law Review 12: 339-360.

Corby B, Doig A \& Roberts V (2001). Public inquiries into residential abuse of children. London: Jessica Kingsley.

Danish Save the Children Fund (2010). Undskyld til grønlænderbørnene [Apology to the Greenlandic children]. Home page 4th September 2010.

http:// www.redbarnet.dk/Nyhed.aspx?ID=25\&Action=1\&NewsId=99\&PID=54 (accessed 2012-10-25)

Ericsson K (2009). Samfunnets stebarn [The stepchildren of society]. Oslo: Universitetsforlaget.

Ericsson K (2011). From investigation to research. Paper presented at SHCY conference in New York, June 23-25 2011.

Ferguson H (2007). 'Abused and Looked After Children as 'Moral Dirt': Child Abuse and Institutional Care in Historical Perspective. Journal of Social Policy 36(1):123-139.

Fraser N (1995). From Redistribution to Recognition? Dilemmas of Justice in a 'Post-Socialist' Age. New Left Review 212:68-93.

Fylkesmannen i Sør-Trøndelag (2007). Omsorg og overgrep: Granskning av barnehjem, skolehjem og fosterhjem benyttet av Trondheim kommune fra 1930-årense til 1980-årene [Care and abuse: the investigation of residential schools, children's homes and foster homes hired by the municipality of Trondheim from the 1930s to 1980s]. Trondheim: Trondheim kommune.

Garrett P (2010). 'It is with deep regret that I find it necessary to tell my story': Child abuse in industrial schools in Ireland. Critical Social Policy, 30: 292-306.

Ghosh B, Israely J, \& Moore T (2010). Sins Of the Fathers. Time, 175(12): 34-37. 
Hayner P (2011). Unspeakable truths: transitional justice and the challenge of truth commissions. 2nd ed. London: Routledge.

Hein L (2003). War Compensation: Claims against the Japanese Government and Japanese Corporations for War Crimes. In Torpey J (eds). Politics and the Past. Lanham MD: Rowman \& Litterfield Publishers.

Holzer P and Lamont A (2010). Corporal Punishment: Key Issues. NCPC Resource sheet. Melbourne: Commonwealth of Australia, Australian Institute of Family Studies. http://www.aifs.gov.au/nch/pubs/sheets/rs19/rs19.pdf (accessed 2012-10-25)

HREOC Human Rights and Equal Opportunity Commission (1997). Bringing Them Home: Report of the National Inquiry into Separation of Aboriginal and Torres Strait Islander Children from Their Families. Sydney.

Ibhawoh B (2008). Rethinking Corporate Apologies: Business and Apartheid Victimization in South Africa. In Gibney M, Howard-Hassmann R.E. \& Coicaud J (eds). The Age of Apology: Facing Up to the Past: 271-285. Philadelphia: University of Pennsylvania Press.

Jackson L A (2000). Child sexual abuse in Victorian England. London: Routledge.

James M (2012). A Carnival of Truth? Knowledge, Ignorance and the Canadian Truth and Reconciliation Commission. The International Journal of Transitional Justice 6:182-204.

John Jay College of Criminal Justice (2004). The nature and scope of sexual abuse of minors by Catholic priests and deacons in the United States, 1950-2000. Washington, DC: United States Conference of Catholic Bishops.

Llewellyn J (2002). Dealing with the Legacy of Native Residential School Abuse in Canada: Litigation, ADR, and Restorative Justice. University of Toronto Law Journal 52: 253-300.

Maguire M J and Ó Cinnéide S (2005). 'A good beating never hurt anyone': The Punishment and Abuse of Children in Twentieth Century Ireland. Journal of Social History, 28(3): 635652.

Marrus M (2008). Papal Apologies of Pope John Paul II. In Gibney M, Howard-Hassmann R.E. \& Coicaud J (eds).The Age of Apology: Facing Up to the Past: 259-270. Philadelphia: University of Pennsylvania Press.

McDonald H (2012). Northern Ireland to launch inquiry into clerical child abuse. The Guardian 31 ${ }^{\text {st }}$ May 2012. http://www.guardian.co.uk/uk/2012/may/31/northern-irelandinquiry-child-abuse (accessed 2012-10-31)

Michelson M (2010). Inquiry cites almost 2,000 Dutch Catholic sex abuse reports. Reuters On-line Edition, 9th December 2010. http:// blogs.reuters.com/faithworld/2010/12/09/report-cites-almost-2000-dutch-catholicsex-abuse-reports-this-year/ (accessed 2012-10-24) 
Ministry of Labour (2011).Press release from the Ministry of Labour, Sweden, January 31st 2011. http://www.regeringen.se/sb/d/14202/a/160048 (accessed 2012-10-25).

Musgrove N (2011). History and Healing: the challenge of writing a history of children in out-of-home care. Paper presented at SHCY conference in New York, June 23-25 2011.

Olick J (2007). The politics of regret: on collective memory and historical responsibility. New York: Routledge.

Olsen K (2005). Under the care of Lebensborn: Norwegian war children and their mothers. In Ericsson K, Simonsen E (eds). Children of World War II: The Hidden Enemy Legacy. 1534. Oxford/New York: Berg.

Penglase J (2007). Orphans of the Living: Growing up in 'care' in twentieth-century Australia. 2 ed. Fremantle: Fremantle Press.

Pettersen K-S (2010). Kommunale oppreisningsordninger for tidligere barnevernsbarn: resultater fra en kartleggningsstudie [Municipal redress schemes for former children placed in child welfare: results from a descriptive study]. Oslo: IKRS, Universitetet i Oslo.

Pettersen K-S, Simonsen E (2011). Recognition and rejection - appraising childhood in the Norwegian welfare state. Paper presented at SHCY conference in New York June 23-25 2011.

Rädda barnen (2012). Totalförbjud aga i alla länder! [Introduce a total ban on corporal punishment in all countries!]. Home page:

http:// www.rb.se/vartarbete/internationellt/vald/pages/total-forbjud-aga-i-allalander.aspx (accessed 2012-10-25)

Residential institutions redress board (2010). Annual Report of The Residential Institutions Redress Board 2010, http:/ / www.rirb.ie/annualReport.asp (accessed 2012-10-24)

Rytter M (2011). Godhavnsrapporten: en undersøgelse af klager over overgreb og medicinske forsøg på Drenge- og Skolehjemmet Godhavn samt 18 andre børnehjem i perioden 1945-1976 [The Godhavn inquiry: an inquiry into abuse and medical experiments on the residential school of Godhavn and 18 other children's homes during the period 19451976]. Odense: Syddansk Universitetsforlag.

Sen R, Kendrick A, Milligan I, \& Hawthorn, M (2008). Lessons learnt? Abuse in residential child care in Scotland. Child \& Family Social Work 13: 411-422.

Shea G (1999). Redress Programs Relating to Institutional Child Abuse in Canada. Paper presented for the Law Commission of Canada October 1999

http://dalspace.library.dal.ca/bitstream/handle/10222/10443/Shea\%20Research\%20Redre ss\%20Programs\%20EN.pdf?sequence=1 (accessed 2012-10-24)

Siriam C L (2005). Transitional Justice Comes of Age: Enduring Lessons and Challenges (review of John Torpey eds, Politics and the Past and Jon Elster, Closing the Books). Berkely Journal of International Law 23(2):506-523. 
Sköld J, Foberg E \& Hedstöm J (2012). Conflicting or complementing narratives? Interviewees' stories compared to their documentary records in the Swedish Commission to Inquire into Child Abuse and Neglect in Institutions and Foster Homes. Archives \& Manuscripts 40(1): 15-28.

Smith J M (2001). Remembering Ireland's Architecture of Containment: 'telling' stories in The Butcher Boy and States of Fear. Eire-Ireland: Journal of Irish Studies 36: 111-130.

SOU 2011:61(2011). Vanvård i social barnavård [Final report from the Commission to Inquire into Abuse and Neglect in Institutions and Foster Homes]. Stockholm: Fritzes.

Swain S (2011). The politics of apology: an Australian genealogy. Paper presented at SHCY conference in New York June 23-25 2011.

Tasmanian Ombudsman (2004). Review of Claims of Abuse from Adults in State Care as Children 2004. Report by the Tasmanian Ombudsman. Hobart: Ombudsman Tasmania.

The Scottish Government - Health and Social Care Integration Directorate (2012). National Confidential Forum -A consultation on the creation of a Forum for Adult Survivors of Childhood Abuse in Residential Care. Edinburgh.

http:// www.scotland.gov.uk/Resource/0039/00397630.pdf (accessed 2012-10-31)

Torpey J (2006). Making whole what has been smashed: on reparations politics. Cambridge, Mass.: Harvard University.

Torpey J (2001). 'Making Whole What Has Been Smashed': Reflections on Reparations. Journal Of Modern History, 73(2):333-358.

Waterhouse R (2000). Lost in Care. Report of the Tribunal of Inquiry into the Abuse of Children in Care in the Former County Council Areas of Gwynedd and Clwyd Since 1974. London: Her Majesty's Stationery Office.

Winter J (2001).The Memory Boom in Contemporary Historical Studies. Raritan 21: 52-66. 